\title{
HONOURS TO ORTHOPAEDIC SURGEONS
}

\author{
SIR HERBERT J. SEDDON, C.M.G., D.M., F.R.C.S., F.A.C.S.(Hon.)
}

The accolade of knighthood in one of the most historic orders of Great Britain, that of the Knight-Bachelor, will soon be conferred by Her Majesty the Queen on our good friend Jim Seddon, now Sir Herbert Seddon. Never did any orthopaedic surgeon more fully deserve the honour.

Having been professor of orthopaedic surgery in the University of Oxford at the Nuffield Orthopaedic Centre in collaboration with the late Gathorne Girdlestone, he came to London in 1948 to join H. Jackson Burrows, Dean of the Postgraduate Institute of Orthopaedics in the London University, which had been established in association with the Royal National Orthopaedic Hospital.

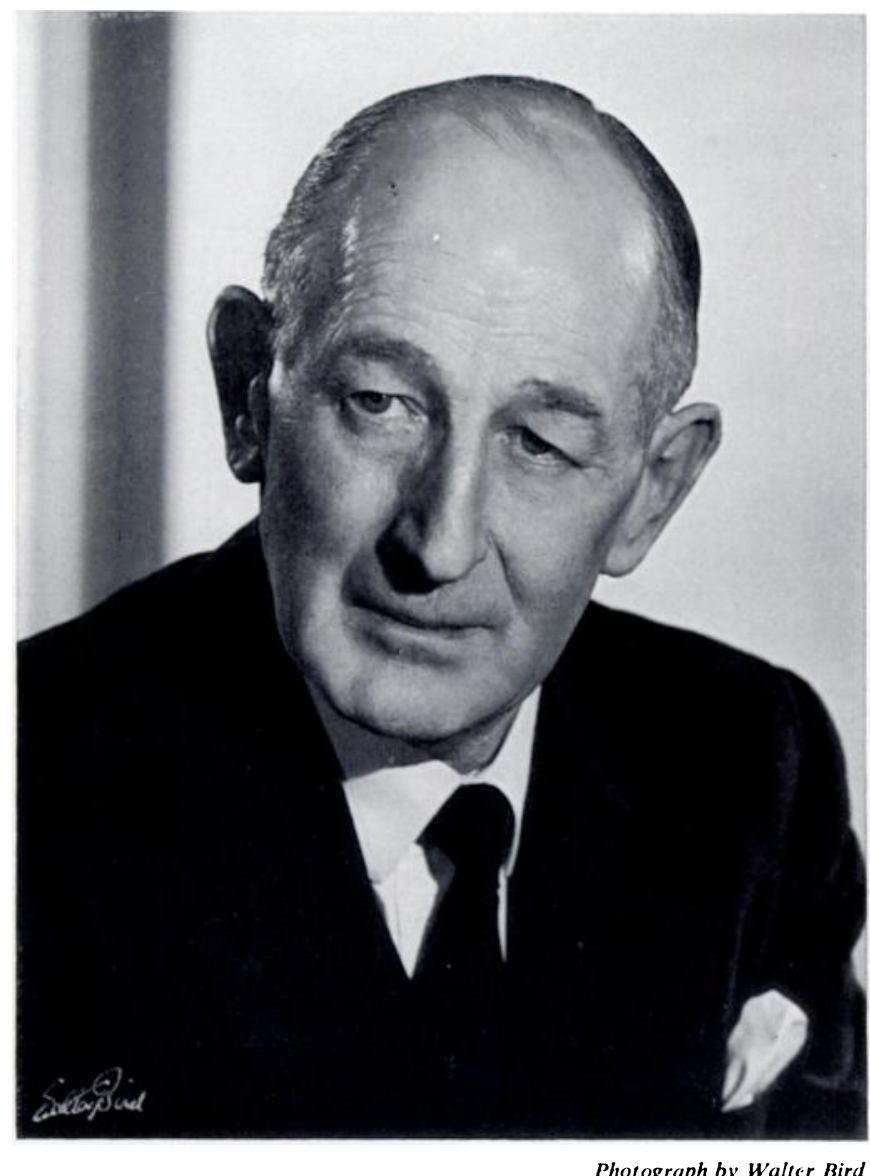

Not only as director of this centre of postgraduate teaching, or as president of the British Orthopaedic Association, already being Robert Jones Prizeman and having made so many important contributions to surgical literature that it would be difficult to list them-they number well over one hundred-he had earlier recognised the duty of developing surgery overseas in the Commonwealth and beyond. In 1943 after dealing with the poliomyelitis epidemic in Malta and soon after another in Mauritius, at the request of the Governor, Lord Gort, he persuaded Lord Nuffield to award a number of postgraduate scholarships to Maltese doctors. He encouraged the development of orthopaedic services in Malta, Mauritius, Kenya,

VOl. $46 \mathrm{~B}$, NO. 1, feBruary 1964

$$
\mathrm{K}-\mathbf{1}_{(8)}
$$


Uganda and Nigeria. Hospitals were built, consultants were trained, registrars seconded and thanks to a generous grant from the Nuffield Foundation, senior consultant medical visitors were appointed to visit the African territories. He was recently concerned with the development of the University of East Africa.

Meanwhile his work continued at home as a member of the Medical Research Council, the Clinical Research Board and the Medical Sub-Committee of the University Grants Committee. He was made an honorary fellow of the American College of Surgeons and of the Brazilian College of Surgeons; he was elected docteur honoris causa in the University of Grenoble. The University of Edinburgh awarded him the Laurence Poole Prize. In the Royal College of Surgeons of England he was Hunterian Professor, Robert Jones Lecturer and Watson-Jones Lecturer.

How great a contribution has been made to orthopaedic surgery by Seddon in this country, its overseas territories and in the American continent. How important has been his contribution to postgraduate medical education in all parts of the world. We congratulate him sincerely.

\section{PROFESSOR WILLIAM GISSANE, C.B.E., F.R.C.S., F.R.A.C.S.(Hon.)}

William Gissane has made an important contribution to the development of accident surgery. His life has been devoted to the treatment of injuries, first at St James's Hospital, London, and then with invaluable emphasis on the need to treat so-called minor injuries as

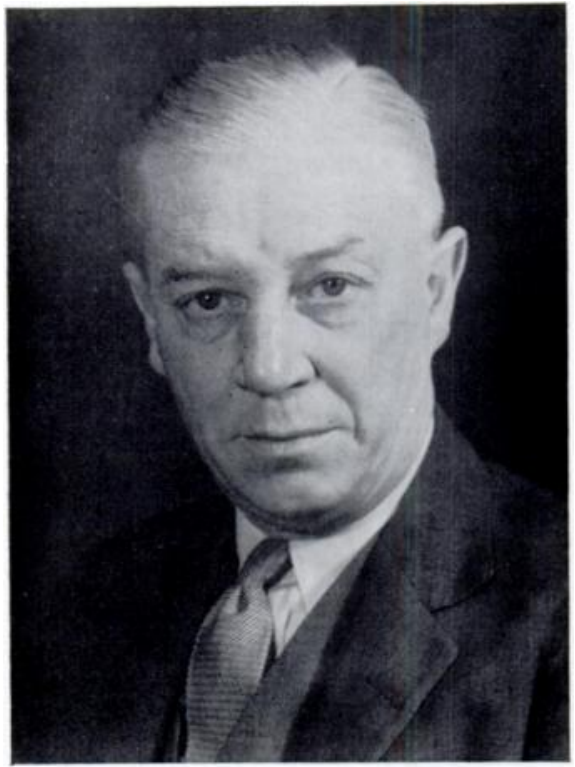
well as major fractures establishing in Birmingham the first Accident Hospital of Great Britain. At a time when there was understandable difference of opinion as to whether casualty and accident services should be developed only in general hospitals or in special accident hospitals, he stood firm and showed the vital need, industrially, economically and socially for the treatment of every injury no matter how trivial it might at first seem with all the skills that could be planned and organised. He insisted that the service of the chief was to be commanded and not just that of the last appointed junior casualty officer. How well he has succeeded.

$\mathrm{He}$ is three times a professor. Wisely allying his accident hospital with the medical school of the University of Birmingham he is now Professor of Accident Surgery. He had been a Hunterian Professor of the Royal College of Surgeons of England; and then carried his torch abroad as Arthur Sims Commonwealth Travelling Professor.

He directs the Hospital and Road Injuries Research Committees of England and has collaborated with American colleagues in endeavouring to solve the problems not only of road highway injuries but of all injuries including those in the home.

We record with warm satisfaction that Her Majesty the Queen will confer upon him the honour of Commander of the British Empire and we congratulate him on this signal recognition of his life's work. 